\title{
ANALISIS TITIK IMPAS SEBAGAI ALAT PERENCANAAN LABA \\ PADA \\ PT. SEMEN INDONESIA TBK. YANG TERDAFTAR DI BURSA EFEK \\ INDONESIA (BEI)
}

\author{
Hasdiana S \\ Idham Khalid \\ Fakultas Ekonomi dan Bisnis, Universitas Muslim Maros \\ 1) email : hasdiana@umma.ac.id
}

\begin{abstract}
ABSTRAK
Penelitian ini bertujuan untuk mengetahui, mengukur, dan menganalisis titik impas dalam merencanakan laba pada PT. Semen Indonesia Tbk yang terdaftar di Bursa Efek Indonesia (BEI). Data yang digunakan dalam penelitian ini adalah data sekunder berupa laporan keuangan PT. Semen Indonesia, Tbk periode 2014-2018 yang terdaftar di Bursa Efek Indonesia. Metode analisis dalam penelitian ini menggunakan Break Even Point dalam unit, Break Even Point rupiah, pendekatan grafik dan margin of safety. Hasil penelitian menunjukkan bahwa BEP unit pada tahun 2014 sebesar 3.972 ton, tahun 2015 sebesar 4.752 ton, tahun 2016 sebesar 5.109 ton, tahun 2017 sebesar 7.671 ton, dan pada tahun 2018 sebesar 5.955 ton, sedangkan BEP dalam satuan rupiah memperoleh hasil dari tahun 2014 sebesar Rp. 3.720.053.245;,tahun 2015 sebesar Rp. 4.459.008.130;, tahun 2016 sebesar Rp. 4.575.517.854, tahun 2017 sebesar Rp. 6.785.017.518;, dan tahun 2018 sebesar Rp. 5.552.468.129. Dan volume penjualan yang harus direncanakan PT. Semen Indonesia Tbk pada tahun 2014 berada di atas Rp.3.720.053.245, tahun 2015 sebesar Rp.4.459.008.130, tahun 2016 sebesar Rp.4.575.517.854, tahun 2017 sebesar Rp.6.785.013.518, tahun 2018 sebesar Rp. 5.522.468.129
\end{abstract}

Kata kunci: Break Even Point, pendekatan grafik, dan Margin Of Safety

\section{ABSTRACT}

This study aims to determine, measure, and analyze the break-even point in planning profit at PT. Semen Indonesia Tbk which is listed on the Indonesia Stock Exchange (IDX). The data used in this study are secondary data in the form of financial statements of PT. Semen Indonesia, Tbk for the period 2014-2018 which is listed on the Indonesia Stock Exchange. The method of analysis in this study uses Break Even Points in units, Rupiah Break Even Points, graphical approaches and margin of safety. The results showed that BEP units in 2014 amounted to 3,972 tons, 2015 amounted to 4,752 tons, 2016 amounted to 5,109 tons, 2017 amounted to 7,671 tons, and in 2018 amounted to 5,955 tons, while BEP in rupiah units got results from 2014 of Rp. 3,720,053,245; in 2015 amounting to $R p .4,459,008,130$; in 2016 amounting to $R p$. 4,575,517,854, in 2017 amounting to Rp. 6,785,017,518 ; and in 2018 amounting to Rp. 5,552,468,129. And the sales 
volume that must be planned by PT. Semen Indonesia Tbk in 2014 was above Rp. 3,720,053,245, in 2015 amounting to Rp. 459,008,130, in 2016 amounting to Rp. 4,575,517,854, in 2017 amounting to $R p$. 6, 785,013,518, in 2018 amounting to $R p$. 5,522,468, 129

Keywords: Break Even Point, graphic approach, and Margin Of Safety

\section{PENDAHULUAN}

\section{A. Latar Belakang}


JURAL ПMПAH sammagran
P-ISSN 2615-6849, E-ISSN 2622-3686

Jurnal Semarak,Vol. 3,No.3, OKTOBER 2020, Hal (153-167)

@Prodi Manajemen Fakultas Ekonomi Universitas Pamulang
Bagi pelaku usaha hal yang paling utama dalam kegiatan bisnisnya adalah mendapatkan laba. Setiap laba atau profit ini selalu menjadi tujuan utama dalam kegiatan bisnis. Karena dengan perolehan laba yang tinggi diharapkan mampu melakukan kegiatan produksi secara penuh serta dapat memberikan manfaat bagi masyarakat luas. Dengan demikian semakin tinggi tingkat perolehan laba maka semakin tinggi pula kemampuan perusahaan melakukan kegiatan produksi.

Kemampuan manajemen dalam perusahaan untuk memperoleh laba ini dipengaruhi oleh banyak faktor. Salah satunya adalah strategi dalam menentukan harga jual dari barang yang di produksinya. Penentuan strategi ini dilakukan dengan bijak melalui pengamatan kegiatan perusahaan periode sebelumnya serta mampu memprediksi peluang di masa yang akan datang.

Perolehan laba pun juga menjadi fokus utama dalam manjemen perusahaan. Jumlah laba yang diperoleh tidak hanya untuk memenuhi kebutuhan produksi saja melainkan untuk berbagai komponen variabel cost lainnya. Sebut saja untuk membayar gaji karyawan, deviden bagi pemegang saham dan lainnya. Sehingga laba yang akan ditargetkan pada periode yang akan datang perlu direncanakan dengan baik.

Dalam merencanakan laba, pihak manajemen perusahaan memerlukan sejumlah alat bantu seperti jumlah biaya yang dikeluarkan setiap periode baik biaya tetap (fixed cost) maupun biaya yang jumlahnya selalu berubah (variabel cost) dan mengukur target perolehan laba pada periode mendatang.

Salah satu alat yang dipakai dalam mengukur jumlah biaya dan perolehan laba adalah menggunakan analisis titik impas atau break event poin analysis. Analisis dengan menggunakan metode ini akan memberikan gambaran bagi manajemen perusahaan bahwa nilai suatu barang yang dihasilkan berada pada kondisi impas atau belum memperoleh laba namun juga tidak mengalami kerugian. Sehingga melalui analisis ini perusahaan akan mampu menambah nilai laba yang direncanakan pada setiap unit produk. Besar atau kecilnya laba yang direncanakan semua tergantung pada kebijakan masing-masing perusahaan dalam menentukan harga jual.

Merencenakan laba dengan metode titik impas ini tidak hanya berlaku bagi perusahaan berskala kecil saja, namun 
JURAL ПMПAH samparan
P-ISSN 2615-6849, E-ISSN 2622-3686

Jurnal Semarak,Vol. 3,No.3, OKTOBER 2020, Hal (153-167)

@Prodi Manajemen Fakultas Ekonomi Universitas Pamulang perusahaan berskala besar pun tetap menggunakan metode ini jika dianggap mampu mewujudkan tujuan perusahaan. Salah satu perusahaan yang mengukur perencanaan laba adalah PT. Semen Indonesia Tbk. Produk berupa semen yang dihasilkan memerlukan perhitungan harga pokok penjualan agar tercapainya laba yang diinginkan. Dengan mengacu pada laporan keuangan yang di rilis melalui Bursa Efek Indonesia periode tahun 2015 hingga 2018 menunjukkan perolehan laba yang berfluktuasi tapi cenderung meningkat. Perolehan laba ini tentu diawali dengan target-target yng ingin capai pada periode mendatang. Sehingga pada capaian ini PT Semen Indonesia mengukur perolehan laba yang dinginkan dengan menggunakan analisis titik impas.

Kecenderungan perubahan penjualan yang meningkat setiap tahunnya namun laba bersih yang diperoleh mengalami fluktuasi yang

\section{B. Perumusan Masalah}

Dari uraian fenomena diatas maka yang menjadi rumusan masalah apakah analisis titik impas dapat dijadikan alat untuk merencanakan laba pada PT. Semen cenderung menurun menjadi hal menarik untuk di analisa lebih lanjut. Perubahanperubahan tersebut akan mempengaruhi tingkat keuntungan. Sehingga kondisi titik impas perusahaan dapat dijadikan sebagai alat untuk perencanaan laba dan tentunya hal tersebut perlu dianalisis lebih lanjut.

Model analisis BEP ini paling sering digunakan untuk mengetahui hubungan antara biaya, volume penjualan, dan laba. Sehingga titik impas juga disebut sebagai suatu titik atau keadaan di mana dalam operasi perusahaan tidak memperoleh laba dan tidak menderita rugi. Atau dengan kata lain jumlah pendapatan sama dengan biaya yang dikorbankan perusahaan.

Berdasarkan uraian diatas, maka dalam penelitian ini akan membahas tentang "Analisis Titik Impas sebagai Alat Perencanaan Laba pada PT. Semen Indonesia Tbk yang Terdaftar di Bursa Efek Indonesia (BEI)"

Indonesia Tbk sebagai perusahaan yang berskala besar.

\section{Tujuan Penelitian}

Untuk menguji keandalan variabel titik impas dalam membuat perencanaan laba perusahaan pada PT Semen Indonesia, Tbk sebagai salah satu perusahaan tambang Page | 156 
JRNAL ПMПAH Sampang
P-ISSN 2615-6849, E-ISSN 2622-3686

Jurnal Semarak,Vol. 3,No.3, OKTOBER 2020, Hal (153-167)

@ Prodi Manajemen Fakultas Ekonomi Universitas Pamulang semen yang terdaftar di Bursa Efek Indonesia (BEI)

\section{TINJAUAN PUSTAKA}

\section{A. Analisa titik Impas}

Beberapa pakar akuntansi mengungkapkan bahwa titik impas adalah suatu kondisi di mana perusahaan yang dalam aktivitasnya tidak memperoleh laba namun juga menderita kerugian, artinya seluruh biaya itu dapat ditutupi oleh penghasilan yang diperoleh dari kegiatan penjualan (Harahap, 2007, p. 358).

Pada penelitian lainnya mengungkapkan bahwa Break Even Point (BEP) merupakan suatu kondisi perusahaan yang mana dalam operasionalnya tidak mendapat keuntungan dan juga tidak mendapat kerugian. Dengan kata lain antara pendapatan dan biaya pada kondisi yang sama sehingga labanya nol. Analisa BEP adalah teknik analisa utuk mempelahi hubugan antara volume penjualan dan profitabilitas. Analisa ini juga disebut analisa impas yaitu suatu metode untuk menentukan titik tertentu dimana penjualan menutupi biaya, sekaligus menunjukkan besarnya keuntungan atau kerugian perusahaan jika penjualan melampui atau berada dibawah titik (Maruta, 2018)

Dari berbagai penelitian terdahulu membuktikan bahwa Analisis titik impas ini bukan sekedar alat yang digunakan tanpa metode pengukuran yang benar. Dengan menentukan teknik yang sesuai maka tujuan untuk mencapai laba yang inginkan bisa terwujud.

(Riyanto, 2008, p. 359) menyebutkan bahwa titik impas adalah suatu teknik yang digunakan unutk menguji hubungan antara biaya variabel yang dikeluarkan oleh perusahaan, laba dan banyaknya kegiatan yang dilakukan oleh perusahaan .

(Sutrisno, 2013, p. 177) berpendapat bahwa dalam analisis titik Impas adalah suatu momen di mana pada saat itu perusahaan tidak memperoleh kelebihan atas penjualan dan juga tidak menderita kerugian, artinya pada saat itu hasil yang diperoleh sama dengan biaya yang dipakai untuk melakukan aktivitas usaha.

Berdasarkan uraian tersebut, maka dapat disimpulkan bahwa titik impas adalah volume penjualan yang terjadi di mana pendapatan yang diperoleh sama dengan biaya-biaya yang telah dikeluarkan. 
JURAL ПMПAH samengard
P-ISSN 2615-6849, E-ISSN 2622-3686

Jurnal Semarak,Vol. 3,No.3, OKTOBER 2020, Hal (153-167)

@Prodi Manajemen Fakultas Ekonomi Universitas Pamulang

\section{B. Asumsi dasar analisis titik impas}

Sebelum menganalisa lebih lanjut tentang titik impas, sebaiknya harus ditelaah kembali asumsi yang mendasari adanya metode ini. (Supomo, 2003, p. 58) dengan melihat beberapa defenisi sebelumnya tentang laba dan konsep biaya maka dapat dijelaskan asumsi yang mendasari hal tersebut :

a. Harga jual setiap unit tidak akan berubah pada setiap volume penjualan yang terjadi

b. Pengelompokan antara biaya tetap dan biaya yang selalu berubah atau biaya variabel. Biaya tetap dipastikan tidak akan berubah pada kapasitas produksi tertentu. Sedangkan biaya variabel akan berubah sesuai dengan porsi kegaiatan yang dilakukan oleh perusahaan

c. Asusmsi kapasitas produksi pabrik selalu konstan

d. Apabila perushaan menjual lebih dari satu macam produk, maka komposisi penjualan juga berubah

\section{Kegunaan analisis titik impas}

(Kasmir, 2010) mengemukan manfaat dari metode analisis titik impas yang dapat membantu manajemen perusahaan dalam melakukan penyusunan perencanaan, diantaranya adalah:

a. Akan tercipat suatu desain produk yang akan diproduk dan direncanakan untuk dijual.

b. Membantu manajemen dalam menentukan harga jual produk

c. Membuat target penjualan dan jumlah yang ingin dicapai

d. Memaksmimumkan jumlah sesuai kebutuhan pasar

Dengan melakukan analisis titik impas ini akan diperoleh pengetahuan tentang hubungan timbal balik yang terjadi antara pendapatan yang diperoleh perusahaan, dan biaya yang dikeluarkan selama melakukan kegiatan produksi. Selain itu dari berbagai manfaat diatas juga dikemukan bahwa dengan analisis ini manajemen akan lebih mudah membuat perencanaan dan mengambil keputusan dalam menjalankan aktivitas produksinya. Manajemen akan diberikan gambaran tentang kapasitas produksi yang harus dinaikkan atau diturunkan agar terhindar dari risiko kerugian. 
JURAL ПMПAH
P-ISSN 2615-6849, E-ISSN 2622-3686

Jurnal Semarak,Vol. 3,No.3, OKTOBER 2020, Hal (153-167)

@Prodi Manajemen Fakultas Ekonomi Universitas Pamulang

\section{Pendekatan dalam analisis titik impas}

Ada dua macam pendekatan dalam analisis titik impas yaitu:

a. Pendekatan matematis

(Riyanto, 2008, p. 364) pendekatan matematis yaitu perhitungan titik pulang pokok dengan menggunakan dua cara matematis yaitu:

1) Titik impas atas dasar unit

$$
B E P(Q)=\frac{F C}{P-V C}
$$

$$
\mathrm{P} \quad=\text { Price (Harga jual perunit) }
$$

$\mathrm{VC}=$ Variable cost (Biaya Variabel Perunit)

FC = Fixed Cost (Biaya tetap)

2) Titik impas atas dasar sales dalam rupiah.

$$
\operatorname{BEP}(\boldsymbol{R P})=\frac{\mathrm{FC}}{1-\frac{\mathrm{VC}}{\mathrm{S}}}
$$

Keterangan:

$$
\begin{aligned}
& \text { FC }=\text { Fixed Cost }(\text { Biaya tetap }) \\
& 1=\text { Konstanta } \\
& \text { VC }=\text { Variable Cost }(\text { Biaya variabel }) \\
& \mathrm{V}=\text { Biaya variabel per unit } \\
& \mathrm{S}=\text { Sales (Penjualan) }
\end{aligned}
$$

b. Pendekatan grafik

Menghitung nilai impas dengan metode grafik ini dapat dilakukan dengan melihat jumlah rupiah dari hasil penjualan yang dilakukan, kuantitas barang yang dijual, biaya-biaya, laba marginal, laba yang diperoleh pada tingkat penjualan tertentu.

Dengan demikian dapat dikatakan bahwa metode titik impas dilakukan untuk menunjukkan volume penjualan, dimana perusahaan tidak memperoleh laba dan tidak juga rugi

\section{E. Perencanaan Laba}

Menurut (Charter \& Milton F, 2006, p. 4)"perencanaan laba (profit planning) adalah tahapan pengembangan dari suatu rencana operasi untuk mencapai tujuan perusahaan".

Sebagai alat ukur dalam keberhasilan perusahaan, laba yang direncanakan juga mengacu pada kegiatan operasional. Untuk itu, Perencanaan laba sebaiknya dilakukan oleh perusahaan dengan mempertimbangkan beberapa faktor seperti yang diungkapkan oleh (Charter \& Milton F, 2006, p. 5) yakni:

a. Besaran keuntungan atau kerugian yang diakibatkan dari jumlah penjualan.

b. Volume penjualan sangat diperlukan untuk menutup semua biaya serta 
JRNAL ПMПAH sampandan
P-ISSN 2615-6849, E-ISSN 2622-3686

Jurnal Semarak,Vol. 3,No.3, OKTOBER 2020, Hal (153-167)

@Prodi Manajemen Fakultas Ekonomi Universitas Pamulang penghasilan laba yang mencukupi untuk membayar deviden dan mampu menyediakan pos untuk kebutuhan bisnis masa depan.

c. Adanya Titik impas atau Break even point.

d. Memperhitungkan kapasitas operasi yang dilakukan perusahaan.

e. Dan memperhitungkan jumlah modal yang digunakan untuk kegiaan usaha.

Dari defenisi tersebut dapat disimpulkan bahwa perencanaan laba dapat diartikan suatu rencana kerja yang telah diperhitungkan dengan baik dan digambarkan secara kuantitatif dalam bentuk laporan keuangan jangka pendek dan jangka panjang.

\section{Manfaat perencanaan laba}

Dengan melihat kondisi persaingan usaha yang terus berubah, maka perusahaan harus menyadari adanya banyak manfaat dari program penganggaran. Yang dimulai dari teknik analisis titik impas. Di antara manfaat tersebut adalah sebagai berikut:

a. Dengan melakukan penganggaran yang baik maka akan terbentuk alat komunika yang tepat bagi manajemen kepada seluruh anggota organisasi. b. Anggaran akan membuat peta kerja bagi manajer untuk merencanakan masa depan perusahaan.

c. Alat untuk mengalokasikan sumber daya yang efektif dan efisien.

d. Manajemen mampu membuat prediksi akan adanya risiko bisnis dimasa yang akan datang.

e. Memudahkan melakukan koordinasi antar anggota dalam perusahaan.

f. Dan anggaran juga membantu dalam mengevaluasi seluruh rangkaian kegiatan perusahaan yang dilakukan.

\section{F. Margin Of Safety (MOS)}

Menurut (Jumingan, 2011) Margin of safety merupakan hubungan antara jumlah penjualan yang dianggarkan dengan jumlah penjualan yang telah dihitung pada kondisi impas. Indikator dari MOS ini adalah ketika nilainya tinggi makan kecenderungan perusahaan untuk mengalami kerugian juga kecil, dan sebaliknya.

(Halim, 2010, p. 413) dalam bukunya Dasar-Dasar Akuntansi Biaya mendefenisikan bahwa Margin Of Safety adalah selisih antara rencana penjualan (dalam unit atau satuan uang) dengan impas (dalam unit atau satuan uang) penjualan. 
JURAL ПMПAH
P-ISSN 2615-6849, E-ISSN 2622-3686

Jurnal Semarak,Vol. 3,No.3, OKTOBER 2020, Hal (153-167)

@ Prodi Manajemen Fakultas Ekonomi Universitas Pamulang
(Brewer., 2006, p. 338) Margin of safety (MOS) dihitung dengan mengurangi jumlah pendapatan yang ditargetkan dengan jumlah penjualan pada keadaan titik impas. Rumus yang digunakan sebagai berikut:

$$
\operatorname{MOS}=\frac{\mathrm{QS}-\mathrm{DS}}{\mathrm{QS}} \times 100 \%
$$

Di mana:

QS = Penjualan yang direncanakan

DS = Penjualan dalam keadaan titik impas

\section{G. Hipotesis Penelitian}

PT. Semen Indonesia Tbk merupakan salah satu perusahaan manufaktur yang ada di Indonesia. Dalam kurun waktu 5 tahun terkahir data yang berfluktuasi pada penjualan dan biaya-biaya, perubahanperubahan tersebut dapat mempengaruhi tingkat keuntungan dan titik impas yang dicapai perusahaan. Hal itu dapat dijadikan sebagai alat analisis dalam melakukan perencanaan laba perusahaan ke depannya.

$$
\text { Berdasarkan pada berbagai }
$$

penelitian terdahulu, kajian teori dan gambaran singkat data yang diperoleh peneliti maka yang menjadi hipotesis dalam penelitian ini adalah bahwa dengan melakukan analisis titik impas maka perusahaan akan dapat merencanakan laba yang akan diperoleh dimasa yang akan datang.

\section{METODE PENELITIAN}

Penelitian ni dilakukan pada objek PT Semen Tonasa, Tbk sebagai salah satu perusahaan manufaktur yang terdaftar di Bursa Efek Indonesia

Metode yang digunakan dalam penelitian ini adalah metode kuantitatif.

Penerapan metode kuantitif ini dengan menganalisa alat ukur yaitu perhitungan titik impas berdasarkan unit yang dihasilkan (diproduksi) oleh perusahaan, titik impas berdasarkan nilai rupiah, dan margin of sale (MOS).

Pengumpulan data dilakukan dengan cara dokumentasi dan melalui tinjauan pustaka yang mendukung teori penelitian untuk mencapai tujuan penelitian.

\section{HASIL DAN PEMBAHASAN}

\section{A. Gambaran Objek Penelitian}

PT. Semen Indonesia (Persero) Tbk (SMGR) bergerak di industri semen. Pabrik semen Perusahaan dan anak perusahaan berlokasi di Gresik dan 
Tuban di Jawa Timur, Indarung di Sumatera Barat, Pangkep di Sulawesi Selatan dan Quang Ninh di Vietnam. Produk Grup dipasarkan di dalam negeri dan internasional. Pemegang saham pengendali Perusahaan adalah Pemerintah Republik Indonesia.

Dengan memiliki setidaknya 16 afiliasi anak perusahaan PT Semen Indonesia mampu mengibarkan bendera produk dengan keunggulan yang kompetitif secara global. Produk nya dikenal dikanca internasional. Stratgegi pengelolaan keuangan yang kuat mampu narik minat para investor asing. Sehingga PT semen Indonesia mampu membagikan deviden dalam jumlah yang cukup besar setiap periodenya.

Ruang lingkup kegiatan perseroan dan anak perusahaan meliputi berbagai kegiatan industri, namun kegiatan utamanya adalah dalam sektor industri semen. PT Semen Indonesia (Persero) Tbk hingga saat ini membawahi 5 perushaan semen di Indonesia diantaranya Semen Gersik, Semen Padang, Semen Tonasa, Thang Long Cemen dan PT Solusi Bangun Indonesia. Dengan memproduksi 6 merek semen yaitu: Semen
Gersik, Semen Padang, Semen Tonasa, Dynamix, Semen Andalas dan Thang Long Cement (Bursa Efek Indonesia)

\section{B. Penemuan dan Pembahasan}

\section{Analisis titik impas}

a. Pendekatan matematis ( unit dan rupiah)

$B E P($ unit $)=\frac{\mathbf{F C}}{\mathbf{P}-\mathbf{V C}}$

$B E P($ Rupiah $)=\frac{\text { FC }}{1-\frac{V C}{P}}$

Dimana:

$\mathrm{BEP}=$ Break Even Point

FC = Biaya Tetap (Fixed Cost)

$\mathrm{P} \quad=$ Harga Jual per unit (Price)

$\mathrm{VC}=$ Biaya Variabel per unit (Variabel Cost)

$1=$ Konstanta

$\mathrm{S} \quad=$ Hasil Penjualan

$\mathrm{V}=$ Biaya Variabel Per tahun

$\frac{\mathrm{V}}{\mathrm{S}} \quad=$ Rumus untuk mencari biaya variabel per unit

Maka perhitungan titik impas dalam rupiah dan perunit pada tahun 2014 adalah sebagai berikut : 
JRNAL ПMMAH

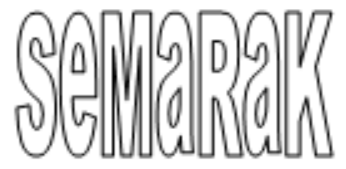

Tahun 2014

Diketahui:

$$
\begin{array}{ll}
\text { FC }(\text { Fixed Cost }) & =\text { Rp. } 1.488 .021 .298 \\
\text { V }(\text { Variabel }) & =\text { Rp. } 16.299 .295 .544 \\
\text { P (Price) } & =\text { Rp. } 946.050 \\
\text { S }(\text { Sales }) & =28.526 \text { Ton } \\
\text { VC }=\frac{V}{S} & \\
\text { VC }=\frac{\text { Rp. 16.299.295.544 }}{28.526 \text { Ton }} \\
\quad=\text { Rp. 571.383 }
\end{array}
$$

$\mathrm{BEP}($ Unit $)=\frac{\mathrm{FC}}{\mathrm{P}-\mathrm{VC}}$

$$
\text { BEP }\left(\text { Unit) }=\frac{\text { Rp. 1.488.021.298 }}{\text { Rp. } 946.050-\text { Rp. } 571.383}\right.
$$$$
\text { BEP }(\text { Unit })=\frac{\text { Rp. } 1.488 .021 .298}{\text { Rp. } 374.667}
$$

$$
\text { BEP }(\text { Unit })=3.972 \text { Ton }
$$$$
\mathrm{BEP}(\text { Rupiah })=\frac{\mathrm{FC}}{1-\frac{\mathrm{VC}}{\mathrm{P}}}
$$$$
\text { BEP }(\text { Rupiah })=\frac{\text { Rp. } 1.488 .021 .298}{1-\frac{571.383}{946.050}}
$$$$
\operatorname{BEP}(\text { Rupiah })=\frac{\text { Rp. } 1.488 .021 .298}{1-0,60}
$$$$
\text { BEP }(\text { Rupiah })=\frac{\text { Rp. 1.488.021.298 }}{0,40}
$$

$$
\text { BEP }(\text { Rupiah })=\text { Rp. 3.720.053.245 }
$$

Dari hasil perhitungan tersebut, dapat diketahui pada tahun 2014 perusahaan PT. Semen Indonesia mencapai titik impas pada tingkat penjualan sebesar 3.972 Ton atau tingkat penjualan sebesar Rp. 3.720.053.245. pada tingkat penjualan tersebut perusahaan tidak menderita rugi dan tidak pula memperoleh keuntungan, dan apabila di atas dari penjualan dalam titik impas tersebut maka perusahaan akan mendapatkan laba dan sebaliknya dibawah dari penjualan titik impas itu akan mengalami kerugian.

\section{Pembuktian}

Penjualan = Rp. 3.720.053.245

Biaya Variabel $=\underline{\text { Rp. 2.232.031.947 }}$ -

$$
\text { Biaya Tetap } \quad=\underline{\text { Rp. } 1.488 .021 .298}
$$

Laba/Rugi $\quad=0$

Dengan melakukan metode perhitungan yang sama maka dapat diketahui pada tahun 2015 perusahaan PT. Semen Indonesia mencapai titik impas pada tingkat penjualan sebesar 4.752 Ton atau tingkat penjualan sebesar Rp. 4.459.008.130.

Kemudian hasil perhitungan tahun 2016 perusahaan PT. Semen Indonesia mencapai titik impas pada tingkat penjualan 


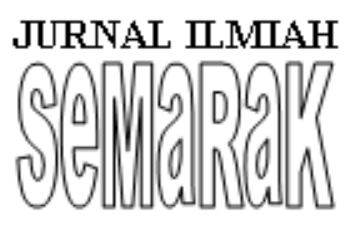

P-ISSN 2615-6849, E-ISSN 2622-3686

Jurnal Semarak,Vol. 3,No.3, OKTOBER 2020, Hal (153-167)

@ Prodi Manajemen Fakultas Ekonomi Universitas Pamulang sebesar 5.109 Ton atau tingkat penjualn sebesar Rp. 4.575.517.854.

Selanjutnya pada tahun 2017 dapat diketahui bahwa PT. Semen Indonesia mencapai titik impas pada tingkat penjualan sebesar 7.671 Ton atau tingkat penjualan sebesar Rp. 6.785.013.518.

Dan pada tahun 2018 Dari hasil perhitungan tersebut, dapat diketahui perusahaan PT. Semen Indonesia mencapai titik impas pada tingkat penjualan sebesar 5.955 Ton atau tingkat penjualan sebesar Rp. 5.522.468.129.

Dengan menggunakan data break event point melalui analisis titik impas diatas maka dapat dibuat model grafiknya.

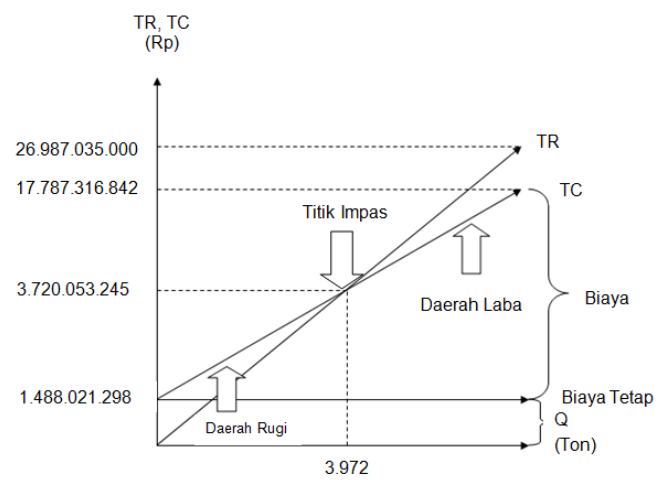

Keterangan :

$$
\begin{array}{ll}
\mathrm{TR} & =(\text { total revenue }) \text { Total penjualan } \\
\mathrm{TC} & =(\text { total cost }) \text { Total biaya } \\
\mathrm{Q} & =\text { Jumlah produksi }
\end{array}
$$

Langkah-langkah yang di tempuh dalam membuat grafik titik impas dengan mengambil data 2014 adalah sebagai berikut

a. Membuat sumbu vertikal (total biaya dan penjualan dan horisontal (jumlah produksi) yang berpotongan di titik nol..

b. Garis biaya tetap sebesar dan sejajar dengan sumbu horizontal.

c. Garis total biaya sebesar Rp.17.787.316.842,- digambar mulai titik biaya tetap pada sumbu vertical ke kanan atas.

d. Garis total penjualan digambar mulai titik nol pojok kiri bawah menuju pojok kanan atas yang di tarik secara diagonal sampai kenilai penjualan sebesar Rp.26.987.035.000,-

e. Terdapat Perpotongan antara garis total penjualan dan biaya maka terlihat titik impas yaitu perusahaan tidak mengalami rugi maupun laba dengan volume penjualan sebesar Rp.3.720.053.245,atau penjualan sebesar 3,972 Ton.

Dan begitupun cara yang ditempuh untuk membuat garfik sebagai gambaran data BEP 
b. Pendekatan margin of sale

Margin of safety dihitung dengan cara sebagai berikut :

$\operatorname{MOS}=\frac{\mathrm{QS}-\mathrm{DS}}{\mathrm{QS}} \times 100 \%$

Dimana :

QS = Penjualan yang direncanakan

DS = Penjualan dalam keadaan titik impas

\section{Tahun 2014}

Diketahui:

QS $\quad=$ Rp.26.987.035.000

DS $\quad=$ Rp.3.720.053.245

$\operatorname{MOS}=\frac{\mathrm{QS}-\mathrm{DS}}{\mathrm{QS}} X 100 \%$

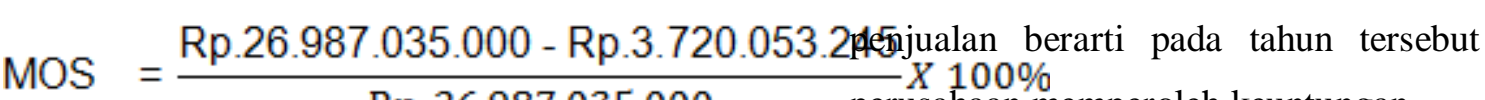
Rp. 26.987 .035 .000

$\operatorname{MOS}=0,862 \times 100 \%$

$=86,21 \%$

Pada tahun 2014 hasil dari perhitungan margin of safety (MOS) yang berarti batas penurunan penjualan tahun 2014 maksimal sebesar 86,21\% apabila penurunan penjualan melebihi $86,21 \%$ maka perusahaan akan menderita kerugian, sebaliknya penurunan penjualan kurang dari $86,21 \%$ maka perusahaan masih mendapatkan laba.
Dan begitupun perhitungan pada tahun selanjutnya.

\section{KESIMPULAN DAN SARAN}

\section{A. Kesimpulan}

1. Nilai yang diperoleh tahun 2014 sebesar Rp.26.987.035.000,- sedangkan volume penjualan pada tingkat titik impas sebesar Rp.3.720.053.245,- artinya apabila PT. Semen Indonesia Tbk. ingin mendapatkan laba maka volume penjualan yang harus direncanakan berada di atas Rp.3.720.053.245. Sehingga berdasarkan nilai penjualan perusahaan memperoleh keuntungan.

2. Nilai perolehan dari aktivitas penjualan tahun 2015 sebesar Rp.26.948.004.000,sedangkan volume penjualan pada tingkat titik impas sebesar Rp.4.459.008.130,- artinya apabila PT. Semen Indonesia Tbk. ingin mendapatkan laba maka volume penjualan yang harus direncanakan berada di atas Rp.4.459.008.130. Sehingga berdasarkan nilai penjualan yang lebih besar dibanding titik impas yang lebih besar dibanding titik impas 
P-ISSN 2615-6849, E-ISSN 2622-3686

Jurnal Semarak,Vol. 3,No.3, OKTOBER 2020, Hal (153-167)

@Prodi Manajemen Fakultas Ekonomi Universitas Pamulang penjualan berarti pada tahun tersebut perusahaan memperoleh keuntungan.

3. Nilai perolehan dari aktivitas penjualan 2016 sebesar Rp.26.134.306.000,sedangkan volume penjualan pada tingkat titik impas sebesar Rp.4.575.517.854,- artinya apabila PT. Semen Indonesia Tbk. ingin mendapatkan laba maka volume penjualan yang harus direncanakan berada di atas Rp.4.575.517.854. Sehingga berdasarkan nilai penjualan yang lebih besar dibanding titik impas penjualan berarti pada tahun tersebut perusahaan memperoleh keuntungan.

4. Nilai yang diperoleha dari aktivitas penjualan tahun 2017 sebesar Rp.27.813.664.000,- sedangkan volume penjualan pada tingkat titik impas sebesar Rp.6.785.013.518,- artinya apabila PT. Semen Indonesia Tbk. ingin mendapatkan laba maka volume penjualan yang harus direncanakan berada di atas Rp.6.785.013.518. Sehingga berdasarkan nilai penjualan yang lebih besar dibanding titik impas penjualan berarti pada tahun tersebut perusahaan memperoleh keuntungan.
5. Nilai perolehan dari aktivitas penjualan 2018 sebesar Rp.30.687.625.000,sedangkan volume penjualan pada tingkat titik impas sebesar Rp.5.522.468.129,- artinya apabila PT. Semen Indonesia Tbk. ingin mendapatkan laba maka volume penjualan yang harus direncanakan berada di atas Rp.5.522.468.129. Sehingga berdasarkan nilai penjualan yang lebih besar dibanding titik impas penjualan berarti pada tahun tersebut perusahaan memperoleh keuntungan.

\section{A. Saran}

Agar perusahaan bisa lebih meningkat hasil produksinya dengan mengacu pada tujuan titik impas sehingga dengan menggunakan alat analisis yang tepat maka perusahaan mampu menghasilkan keuntungan diatas rata-rata target yang ditentukan.

\section{DAFTAR PUSTAKA}

Brewer., E. W. N. dan P. C. (2006). Akuntansi Manajerial (11th ed.). Salemba empat.

Charter, W., \& Milton F, U. (2006). Akuntansi Biaya. Salemba Empat. Halim, A. (2010). Akuntansi Biaya. BPFE. Harahap, S. S. (2007). Analisis Krirtis Atas 


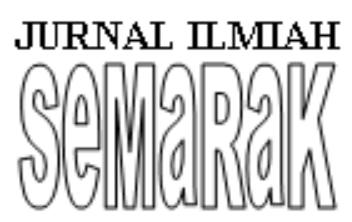

P-ISSN 2615-6849, E-ISSN 2622-3686

Jurnal Semarak,Vol. 3,No.3, OKTOBER 2020, Hal (153-167)

@ Prodi Manajemen Fakultas Ekonomi Universitas Pamulang
Laporan Keuangan. Jakarta: PT.Raja

Grasindo Persada.

Jumingan. (2011). Pengaruh Rasio

Likuiditas, Rasio Leverage Dan Rasio

Aktivitas Terhadap Kinerja Keuangan

Perusahaan. Jurnal Administrasi Bisnis.

Kasmir. (2010). Kasmir. In PENGANTAR

MANAJEMEN KEUANGAN.

Oktrima, B., \& Riani, N. (2019). PENGARUH

\begin{tabular}{llrr} 
PERPUTARAN & \multicolumn{2}{c}{ KAS } & DAN \\
PERPUTARAN & \multicolumn{4}{c}{ PIUTANG } \\
TERHADAP & RETURN & ON \\
INVESTMENT & (ROI) & PADA & PT. \\
SEMEN INDONESIA & (PERSERO) \\
TBK & PERIODE & TAHUN & 2008- \\
2017. Jurnal Ekonomi Efektif, 2(1).
\end{tabular}

Purnomo, S., \& Pasaribu, V. L. D. (2019).

Pergerakan Harga Saham Pt Adaro

Energy Tbk (Adro) Pada Pengumuman

Dividen Interim Tahun Buku

2018. Jurnal Ekonomi Efektif, 2(1).

Maruta, H. (2018). Analisis Break Even

Point (Bep) Sebagai Dasar Perencanaan

Laba Bagi Manajemen. Sekolah Tinggi

Ilmu Ekonomi (STIE) Syariah

Bengkalis.

Riyanto. (2008). Dasar-dasar pembelanjaan

Perusahaan. Edisi Keempat

Yogyakarta.
Supomo, H. dan. (2003). pengertian akuntansi. Journal of Chemical Information and Modeling. https://doi.org/10.1017/CBO97811074 15324.004

Sutrisno. (2013). Manajemen Keuangan Teori Konsep dan Aplikasi. In Manajemen Keuangan Teori Konsep dan Aplikasi.

Virby, S., \& Lidia, E. (2019). ANALISIS PEN, GARUH "PERPUTARAN "K; AS DAN CURRENT RASIO TERHADA, $P$ RETURN ON ASSET DI PT. ULTR, AJAYA MIILK INDUST, RY AND TR, ADING COOMPANY, TBK PERIIODE TAHUN 2008-2017. Jurnal Semarak, 2(3), 161-170. 